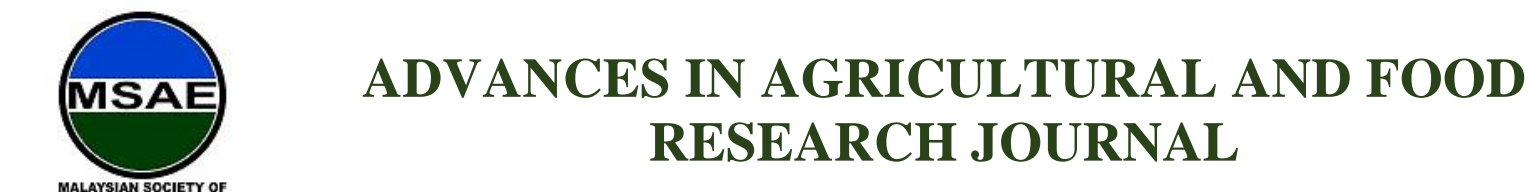

HH PUBLISHER

Original Research Article

\title{
Study on Utilization of Black Soldier Fly Larvae (Hermetia illucens) as Protein Substitute in the Pellet Diet of Clarias gariepenus Fingerling
}

\author{
Noor Ain Abd Hamid ${ }^{1 *}$, Nur Farahiah Zakaria ${ }^{2}$, Nur Aina Lyana Mohamad Ali $^{3}$ \\ ${ }^{1}$ Jabatan Agroteknologi dan Bio-Industri, Politeknik Jeli, Kelantan, Malaysia, noorain@ pjk.edu.my; \\ farahiah@pjk.edu.my; nuraina@pjk.edu.my \\ *Corresponding author: Noor Ain Abd Hamid, Jabatan Agroteknologi dan Bio-Industri, Politeknik Jeli, \\ Kelantan, Malaysia, noorain@pjk.edu.my
}

\begin{abstract}
Fish farming faces the challenge of the high cost of feeds because of the cost of high-quality protein like fish meal required in food formulations. Therefore, the need for alternative protein sources is much needed. Black soldier larvae (Hermetia illucens) are alternative feed containing high protein. BSF larvae contain high protein levels $(42.7 \%$ dry matter; DM). Fish diets should contain $32 \%$ to $45 \%$ protein content. Therefore, it can be a substitute for a fish meal. This study was conducted to investigate the effect of freshwater fish meal replacement with black soldier fly larvae meal (BSFLM) on the growth rate of Clarias gariepenus fingerling. The effect of freshwater fish meal replacement with black soldier fly larvae (BSFLM) was investigated. This study involved the cultivation of Clarias gariepenus fingerling given BSFLM and a commercial diet. The results showed a difference between the weight gains of $C$. gariepenus, which were $6.46 \mathrm{~g}$ in BSFLM, while the commercial diet was $1.9 \mathrm{~g}$ during 28 days of experiments. There was also no significant difference $(p<.05)$ in the mean weight gain, specific growth rate (SGR), and survival rate. Using BSFLM as an alternative source of protein in fish farming can reduce costs in the aquacultureindustry without changing its quality.
\end{abstract}

Keywords: Black Soldier Fly (Hermetia illucens); protein substitute; C.gariepenus fingerlings

Received: $15^{\text {th }}$ February 2021

Received in Revised Form: $13^{\text {th }}$ November 2021

Accepted: $17^{\text {th }}$ November 2021

Available Online: $2^{\text {nd }}$ December 2021

Citation: Abd Hamid, N.A., Zakaria, N. F., \& Mohamad Ali, N. A. L. Study on utilization of black soldier fly larvae (Hermetia illucens) as protein substitute in the pellet diet of Clarias gariepenus fingerling. Adv Agri Food Res J 2022; 3(1): a0000258. https://doi.org/10.36877/aafrj.a0000258

\section{Introduction}

Aquaculture production has increased by around 5.8\% annually due to increased fish production (FAO, 2018). For many years, fishmeal (FM) has been one of the primary sources of protein used in aquaculture feeds for the balance of amino acid composition, high digestibility, and palatability, which help improve digestion and absorption of nutrients in fish. (Miles \& Chapman, 2006). 
Most aquaculture fish use formulated feeds and intensive carnivorousfish production using good fish meal (FM) and fish oil sources. Fish meal is a significantcomponent of fish feeds that is very limited but competitive for consumers and is a costly source in fish feed formulation. The objective is to reduce the consumption of fish meals and, at the same time, maintain the quality of protein in fish feed. However, the high demand for aquaculture feeds led to a rapid rise in prices for these commodities (FAO, 2016). Many studies have been done to reduce fish meal and fish oil use by replacing them with alternative proteins to solve these problems. The provision of suitable and economical fish diets can increase fish production worldwide.

Insects are high in protein and are suitable for animal feed. The protein content in insectsis equivalent to protein from fishmeal and soybean meal, especially the composition of lipids,amino acids, minerals, and vitamins (Henry et al., 2015). Dependence on the use of fish mealin fish diets production has affected aquaculture profits (Jamu \& Ayinla, 2003; Olsen \& Hasan, 2012) and environmental sustainability (Collavo et al., 2015). Excessive exploitationof wild fish, especially aqua feed production and fish oil, has caused continuous disruptionto the aquatic feed net.

This harms this sustainability commodity. In addition, the stock of fish meal and fish oil was insufficient due to the availability of wild fish resources. The impact of this problem has led to the search for more economical and sustainable alternativefeed sources such as Black Soldier Fly (Hermetia illucens) (BSFLM).

Hermetia illucens is an insect suitable for mass production due to its assimilation of nutrients from various organic wastes and converts them into high-quality nutrients (protein content more than $40 \%$ and lipid content more than 30\%) for fish feed production (St-Hilaire et al., 2007; Yu et al., 2009; Makkar et al., 2014; Henry et al., 2015).

A study report by Belghit et al. (2019) showed that $H$. illucens larvae meal could substitute fish meal in Atlantic salmon feed without changes in fish performance and digestion.

Similarly, to the study by Dietz and Liebert (2018) and Xiao et al. (2018), fish and soy bean meals were replaced by $48 \%$ and $50 \%$ in the diet of yellow catfish and nile tilapia. Studies have been conducted on yellow catfish fed BSF meal (Xiao et al., 2018), butthere is no African catfish data. Therefore, the purpose of this research was to examine the effects of black soldier fly larvae as a protein substitute in the pellet diet of Clarias gariepenus fingerling to increase growth rate while reducing the cost of the fish meal. The demand for this fish is very high in Malaysia.

\section{Materials and Methods}

\subsection{Dry pellet processing}

The BSF larvae meal (BSFLM) was purchased from the Eco-Farm Company. The BSFLM produced will contain protein levels at a rate of $40 \%$. The protein content of BSF 
pellets is similar to the commercial pellet. The processed BSFLM dried diets were stored in plastic bags at $4{ }^{\circ} \mathrm{C}$ until further use. The proximate analysis of the BSFLM sample is shown in (Table 1). This study uses a total of 744 grams of BSFLM that were then finely ground into a powder texture using a home blender mill. Three main raw ingredients have been used: BSFLM, tapioca flour, and water with a ratio of 5:2:2, respectively. This BSFLM formulation uses Pearson's Square method. The processing method begins with weighing, grinding, mixing, preconditioning (steam), pelleting, drying, coating and packing. Briefly, the powdered BSFLM was mixed with tapioca flour and water. Water was added, and the mixture was kneaded by hand to produce a dough. The dough was steamed using a boiler for 1 hour to realize starch gelatinization and deactivating anti-nutritional factors. The finished steamed dough is left to cool before making the pellet shape. The pelleting process uses hands. The pellet was dried using a drying oven at $80^{\circ} \mathrm{c}$ for 24 hours. The dried pellet was coated with oil. The finished pellets were sent to the Kedah Biotech Corp for proximate analysis.

Table 1. Proximate analysis of BSF larvae meal.

\begin{tabular}{lc} 
Parameter & Result (Per 100g) \\
\hline Gross energy & $348 \mathrm{kcal}$ \\
Carbohydrate & $40.6 \mathrm{~g}$ \\
Protein & $42.7 \mathrm{~g}$ \\
Fat & $1.6 \mathrm{~g}$ \\
\hline
\end{tabular}

\subsection{Feeding Trial}

\subsubsection{Experimental setup}

The feeding trial used six (6) rectangular plastic aquariums of $34 \times 20 \times 24 \mathrm{~cm}$. The research was carried out in the Fish Propagation House, Politeknik Jeli Kelantan. The project begins with the process of aquarium cleaning and disinfection. Then the aquariums were filled with two-thirds of dechlorinated tap water. Two types of treatment are used: experimental pellets and commercial pellets. Each treatment was replicated thrice. Each aquarium has been equipped with 20 African catfish of average 3.0 inches and fed with their respective diet for 28 days. The fish were hand-fed to apparent satiation with the test diets twice a day (0800 and $1700 \mathrm{~h})$.

\subsubsection{Water quality monitoring}

Observations on water quality parameters (dissolved oxygen, $\mathrm{pH}$ ) are made weekly using the YSI multiparameter and $\mathrm{pH}$ meter. In contrast, a thermometer takes temperature parameters daily before the feeding process at 08.00-08.10 am.

\subsubsection{Calculations and statistical analysis}

Ten fish per replicate aquarium (30 fish per treatment) were taken each week randomly to measure the body mass and standard length. The formulasbelow were used to 
evaluate growth performance among the various experimental groups.

Weight gain $(\mathrm{WG})=$ Final body weight $(\mathrm{g})$ - Initial body weight $(\mathrm{g})$.

Percentage Weight Gain $(\%)=[($ final body weight $(\mathrm{g})$ - initial body weight $(\mathrm{g}))$

/ initialbody weight (g)] x 100

Specific growth rate $(\mathrm{SGR}, \% /$ day $)=[(\ln$ Final body weight $(\mathrm{g})-\ln$ initial body weight $(\mathrm{g}))$ /number of feeding days] $\mathrm{x} 100$

Relative growth rate $=($ Fish Weight gain $/$ Initial body weight $) \times 100$

Specific growth rate $=(\mathrm{Ln} F w-\mathrm{Ln}$ Iw $) / \mathrm{t} \times 100$

Feed Conversion Ratio $=$ Feed fed $(\mathrm{g} / \mathrm{kg}) /$ Weight gain $(\mathrm{g} / \mathrm{kg})$

Survival rate $=($ Number of fish during harvested $/$ Number of fish stocked $) \times 100$

\subsubsection{Statistics}

The data obtained were analyzed using one-way (ANOVA) variance to test for the significant difference in the means. Statistical tests were performed based on SPSS version 10.00. The significance level is set at 0.05 .

\section{Results}

\subsection{BSF Pellet Production}

The proximate composition of the BSF pellet shows in Table 2.

Table 2. Proximate composition of formulated fish feed (\% moisture basis)

\begin{tabular}{lc}
\hline \multicolumn{1}{c}{ Parameters } & BSF pellet \\
\hline Energy & 430 \\
Carbohydrate & $\mathrm{kcal}$ \\
Protein & $40.8 \mathrm{~g}$ \\
Fat & $30.2 \mathrm{~g}$ \\
\hline
\end{tabular}

\subsection{Water Quality Parameters}

Water quality parameters recorded are in the range temperature $25.6-28.4{ }^{\circ} \mathrm{C}$; dissolved oxygen range 5.6-5.7 $\mathrm{mg} / 1$, and $\mathrm{pH}$ range 7.5-8. Optimal water quality parameter results show the high acceptability of feed. No fish deaths occurred during the culture period.

\subsection{Growth Performance}

The effects of BSFLM on the catfish growth rate are presented in Table 3. The performance of formulated diets on the growth of catfish fingerling is very high compared to the control diet.

At the end of the test, BSFLM recorded the highest final body weight, weight gain, WG\%, SGR compared to commercial pellets $(p<.05)$. The results also show no significant difference in all fish's food intake and survival. The survival rate for both foods is $100 \%$. 
Table 3 Growth results of Clarias Gariepinus fingerlings fed on BSFLM and commercial pellet

\begin{tabular}{ccc}
\hline Parameters & BSFLM & Commercial Pellet \\
\hline Mean weight gain (WG, g/fish & 6.46 & 1.9 \\
Percentage Weight Gain (\%) & 85 & 27 \\
Specific growth rate (SGR,\%/day) & 2.19 & 0.86 \\
Survival (\%) & 100 & 100 \\
\hline
\end{tabular}

\section{Discussion}

This study demonstrated the food potential of BSFLM for Catfish culture. The value of (WG, WG\%, and SGR) for fish fed BSF was higher than those fed commercial feed, but the difference value was not significant.

The results of this study clearly show that BSFLM is a feed that is acceptable and well digested by Catfish fingerling. This study aligns with (Magalhães et al., 2017), where there is no difference in growth parameters for European sea bass and other fish species.

Magalhães et al. (2017) also stated that $19.5 \%$ of black soldier fly, H. illucens, successfully replaced $45 \%$ FM in the diets for juveniles of European sea bass, without any adverse effects on growth food consumption and digestion performance.

The results of this study are also in line with the results of Xiao et al. (2018), who stated that $H$. illucens larval meal protein could replace fish meal in the diet of yellow catfish by $48 \%$ without affecting fish growth performance.

The acceptance of fish's high nutrient value of BSF larval feed indicates that this diet can benefit the food industry and fish farmers.

Fed BSF pellets to $C$. gariepinus fingerlings can increase the survival rate. This may be due to the suitability of fish to the BSF larvae-based diet, providing better conversion and consumption of feed. This is supported by Holm and Torrisen (1987), who stated that feeding from insects and living organisms could enhance a healthy state and survival.

\section{Conclusion}

This study has shown that BSFLM is a feed that can be an excellent potential source of protein to replace fishmeal in African catfish. The use of BSF larval feed in the diet of C.gariepinus has a good potential of reducing the cost of fish farming and increasing the aquaculture sector's production. This study was preliminaryand more research needs to be done to develop alternative feed proteins so that these protein sources can meet the demands of breeders.

Acknowledgments The authors would like to thank Politeknik Jeli Kelantan's management and thank everyone involved in this project.

Conflicts of Interest: We declare that no known conflicts of interest have appeared in this paper. 


\section{References}

Belghi, I., Liland, N. S., Gjesdal., P., et al. (2019) . Black soldier fly larvae meal can replace fish meal in diets of seawaterphase Atlantic salmon (Salmo salar). Aquaculture, 503, 609-619.

Collavo, A., Glew, R.H., Huang, Y.S., et al. (2005). House cricket small-scale farming. In Ecological Implications of Mini Livestock: Potential of Insects, Rodents, Frogs and Snails; Paoletti, M.G., Ed.; Science Publishers: Enfield, NH, USA,519-544.

Dietz, C. \& Liebert, F. (2018). Does graded substitution of soy protein concentrate by an insect meal respond on growth and $\mathrm{N}$-utilization in Nile tilapia (Oreochromis niloticus). Aquaculture Reports, 12, 43-48

FAO. (2016). Contributing to food security and nutrition for all. The state of world fisheries and aquaculture, Rome (200pp)

FAO. (2018). Meeting the Sustainable Development Goals, The State of World Fisheries and Aquaculture. FAO Rome, Italy.

Henry, M., Gasco, L., Piccolo, G., et al. (2015). Review on the use of insects in the diet of farmed fish: Past and future. Animal Feed Science and Technology, 203, 1-22

Holm, J. C. \&, Torrisen, K. R. (1987). Growth depression and acclimatization if protease in Atlantic salmon firstfeeding fryresponding to a diet supplemented with Zooplankton. Aquaculture, 65.

Jamu, D. M. \& Ayinla, O. A. (2003). Potential for the development of aquaculture in Africa. NAGA, WorldFish Center Quarterly, 26, 9-13.

Magalhães, R., Sánchez-López, A., Leal, R.S., et al. (2017). Black soldier fly (Hermetia illucens) pre-pupae meal as a fish meal replacement in diets for European sea bass (Dicentrarchus labrax). Aquaculture, 476, 79-85

Makkar, H. P. S., Tran, G., Heuzé., V., et al. (2014). State-of-the-art on use of insects as animal feed. Animal Feed Science and Technology, 197(2014), 1-33

Miles, R. D. \& Chapman, F. A. (2006). The benefits of fish meal in aquaculture diets. IFAS Extension, University of Florida, USA.

Olsen, R. L. \& Hasan, M. R. (2012). A limited supply of fishmeal: Impact on future increases in global aquaculture production. Trends in Food Science and Technology, 27, 120-128.

St. Hilaire, S., Sheppard, C., Tomberlin, J. K., et al. (2007). Fly pre-pupae as a feedstuff for rainbow trout, Oncorhynchus mykiss. Journal of the World Aquaculture Society, 38(1), 59-67.

Xiao, X., Jin, P., Zheng, L., et al. (2018). Effects of black soldier fly (Hermetia illucens) larvae meal protein as a fishmeal replacement on the growth and immune index of yellow catfish (Pelteobagrus fulvidraco). Aquaculture Research, 49(4), 1569-1577.

Yu, G. H., Chen, Y. H., Yu., Y. H., et al. (2009). Research progression on the larvae and prepupae of black soldier fly Hermetiaillucens used as animal feedstuff. Chinese Bulletin of Entomology, 46(1), 41-45. 